\title{
Preliminary Studies on Antimicrobial Activity of Extracts from Aloe Vera Leaf, Citrus Hystrix Leaf, Zingiber Officinale and Sabah Snake Grass Against Bacillus Subtilis
}

\author{
M.N.A. Uda ${ }^{1}$, Subash C.B. Gopinath ${ }^{1,2}$, Nur Hulwani Ibrahim ${ }^{1}$, Mohd Khairul Rabani Hashim ${ }^{l}$, M.A. Nuradibah ${ }^{l}$, M.N. \\ Salimi $^{1}$, Tan Ewe Shen ${ }^{1}$, Ong Yee Fen ${ }^{1}$, Maisara A. M. Akhir ${ }^{1}$, U. Hashim ${ }^{2}$ \\ ${ }^{1}$ School of Bioprocess Engineering, Universiti Malaysia Perlis, 02600 Arau, Perlis, Malaysia. \\ ${ }^{2}$ Institute of Nano Electronic Engineering, Universiti Malaysia Perlis, 01000 Kangar, Perlis, Malaysia.
}

\begin{abstract}
Herbal plants have several potential antimicrobial activities either as antifungal or antibacterial to fight against the disease and pathogen that attack the plants. The extractions of the Aloe vera leaf, Citrus hystrix leaf, Zingiber officinale rhizome and Sabah snake grass were selected in this study to fight against Bacillus subtilis. B. subtilis is a Gram-positive bacterium, rodshaped and catalase-positive that lives on decayed organic material. It is known as Gram-positive bacteria because of its thick peptidoglycan and would appear purple when subjected to Gram test. This species is commonly found in the upper layers of the soil, in meat or vegetables, in pastry, cooked meat, in bread or poultry products. The extracts of Sabah Snake Grass found to be most effective than A.vera leaf, Z. officinale, and C. hystrix against the B. subtilis.
\end{abstract}

\section{Introduction}

Herbal medicine has been widely used all over the world and formed an integral part of primary health care in many countries. Since ancient times, many plants species reported to have pharmacological properties as they are known to possess various secondary metabolites which utilized to combat the disease-causing pathogens [1]. In this study, there are three types of plants which are Aloe vera leaf, Citrus hystrix leaf and Zingiber officinale rhizome used for testing their antimicrobial against $\mathrm{B}$. subtilis.

Aloe vera is a perennial, drought resisting, succulent plant. It has stiff green, lance-shaped leaves containing clear gel in a central mucilaginous pulp [2]. Aloe is a plant widely used in alternative medicine. There are about 420 different plant species of Aloe. Aloe vera is currently growing worldwide in tropical and subtropical areas. The concentrated extracts of Aloe leaves are used as antimicrobial. The clear gel of Aloe vera contains a wide range of enzymes which provides many benefits including antibacterial ability and also can help to soothe the skin and treat the sunburn. The extraction of the plants herbs that have antimicrobial properties can be used for great treatment in order to fight against several fungi or bacterial infections [3].
Second is C. hystrix leaf. C.hystrix is highly respected in herbal medicine, due to its high content of beneficial organic compounds that can positively affect the body's systems. The leaf are the richest part of the plant and highly aromatic. They are easy to store since they can be frozen for many months without losing flavour. Ratseewo and researchers reported that the volatile compounds found in C. hystrix leaf oil were citronellal, linalool, $\beta$-cubebene, $\beta$-pinene, myrcene, limonene, $\gamma$ terpinene, $\rho$-cymene, terpinolene, copaene, caryophyllene, citronellyl acetate, citronellol, geranyl acetate and $\delta$-cadinene [4].

Other than A. vera and C.hystrix, Z. officinale and Sabah snake grass also is a promising plant material with numerous biological activities [5]. Z. officinale has long been used as naturopathy due to their potential antimicrobial activity against different microbial pathogens [6]. Z.officinale or ginger belongs to Zingiberaceae family. Nutrient composition of fresh $\mathrm{Z}$. officinale contains $80.9 \%$ moisture, $2.3 \%$ protein, $0.9 \%$ fat, $2.4 \%$ fiber and $12.3 \%$ carbohydrates. The minerals present in it are iron, calcium and phosphorous. It also contains vitamins such as thiamine, riboflavin, niacin and vitamin $\mathrm{C}$. The part of the plant used is rhizome (underground stem). Z. officinale contain antimicrobial property against test microbes [2]. Other studies reveal

\footnotetext{
* Corresponding author: author@e,-mail.org
} 
that $Z$. officinale root contains several ingredients which have antifungal properties, with shagelol and gingerol being the most active [8]. The bacteria used in this study are B. subtilis. B. subtilis is a gram-positive bacterium and readily present bacteria because of its thick peptidoglycan and would appear purple when subjected to Gram test [9].

\section{Methodology}

2.1 Extractions process of $A$. vera leaf, $C$. hystrix leaf, Z. Officinale and Sabah snake grass

Firstly, the Aloe leaves are dried in the oven at $80^{\circ} \mathrm{C}$ for $48 \mathrm{hr}$. For Z. officinale, it was dried for only 5 hours and 30 minutes and C. hystrix leaf was dried for only 30 seconds. After that, the samples that have been dried are crushed into the small pieces using the blender until it became powdered. The solvent used is ethanol. For the preparation of ethanol, $20 \mathrm{~g}$ of each samples powder is soaked in $100 \mathrm{ml}$ of the solvent and put on incubator shaker for $24 \mathrm{~h}$. The mixed solutions then are filtered and were kept in the refrigerator until further use. The diagram below shows an overview of different types of extractions process.

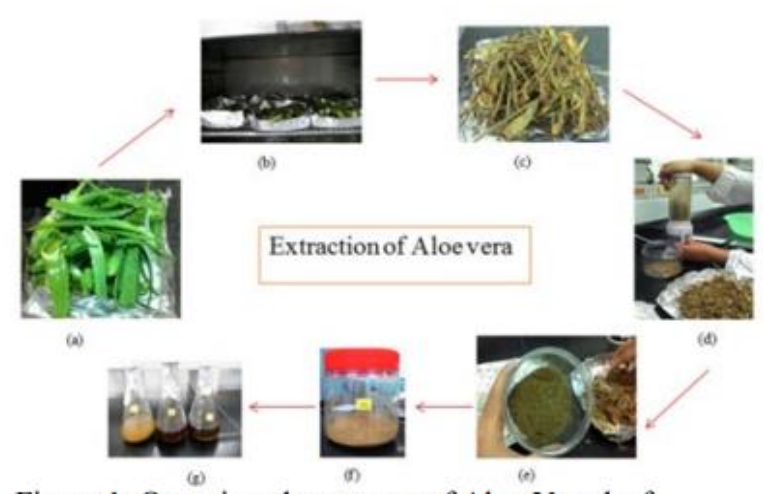

Figure 1: Overview the process of Aloe Vera leaf extraction

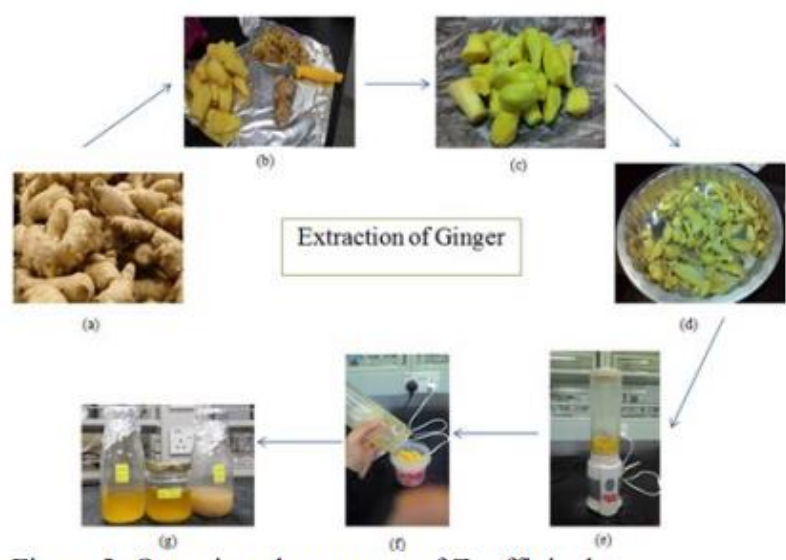

Figure 2: Overview the process of $\mathrm{Z}$. officinale extraction

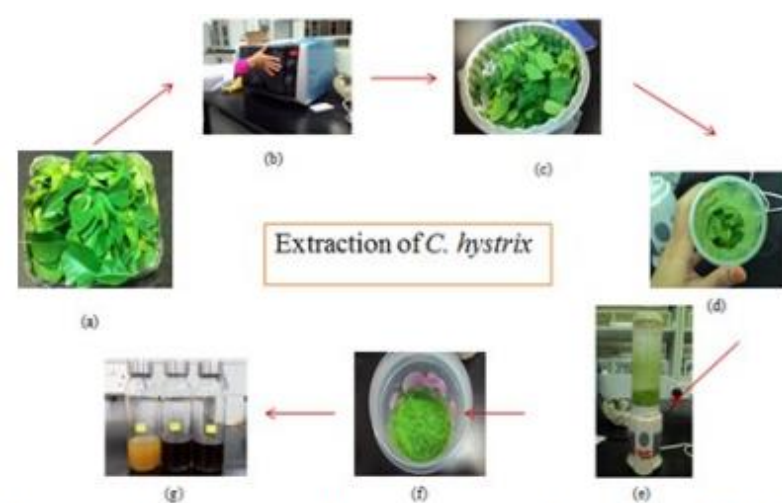

Figure 3: Overview the process of C. hystrix leaf extraction

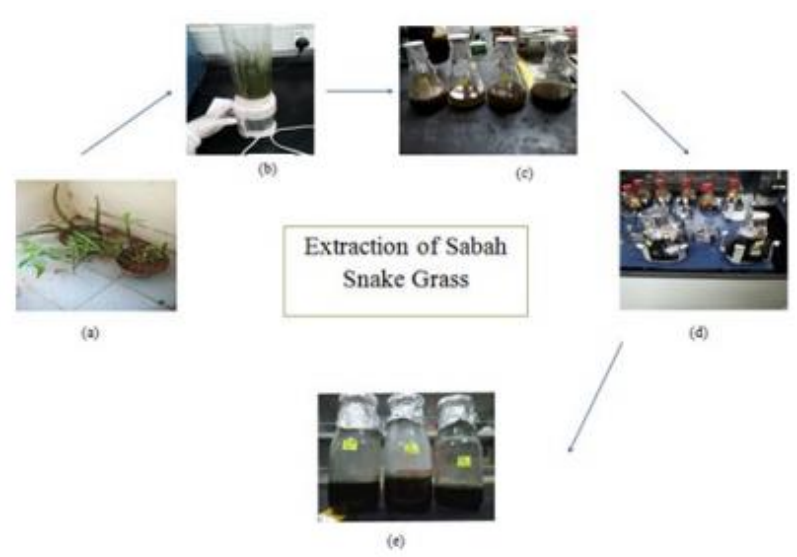

Figure 4: Overview the process of Sabah snake grass leaf extraction

\subsection{Preparation of nutrient agar (NA)}

NA was prepared by dissolving $20 \mathrm{~g}$ of nutrient powder with $1 \mathrm{~L}$ of distilled water in a scotch bottle. The bottle then is shaking many times for even mixing. After that the scotch bottle is autoclaved for 15 minutes. Then, the scotch bottle is taken out from the autoclave machine and placed it in the laminar flow and allows it to cooling down. Next, the NA was poured into petri dish and allowed it to solidify.

\subsection{Culturing $B$. subtilis on NA}

B. subtilis was obtained from the laboratory in School of Bioprocess Engineering, University Malaysia Perlis (UniMAP), Perlis. B. subtilis was streaked on NA plate and incubated at $37{ }^{\circ} \mathrm{C}$ for 24 hours.

\subsection{Screening of antimicrobial activity}

Screenings of antimicrobial activity are performed by standard disc diffusion method [10]. The disc paper is used for evaluating the antimicrobial activity. The discs are prepared from Whatman No. 1 filter paper. The size of the disc is $6 \mathrm{~mm}$. The discs are ensured to sterilized and autoclaved. After the sterilization the moisture discs 
are dried until further use. Then the three plants extracts discs and control discs are prepared.

\subsection{Antimicrobial activity of $A$. vera, C. hystrix, $Z$. officinale and Sabah snake grass}

For the bacteria, two loops is taken from the pure culture of $B$. subtilis using an inoculating loop and mixed with $100 \mathrm{ml}$ of sterile distilled water. Then the mixed solution was spread evenly on NA agar and the disc paper was put on it. The plant extractions with different concentrations $(5,10,20$ and $30 \mathrm{mg} / \mathrm{ml})$ were pipette on it. Then the plates were incubated for 24 hours at $37^{\circ} \mathrm{C}$. Antimicrobial activities are evaluated by measuring the diameter of circular inhibition zones around the disc paper. A positive result is defined as an inhibition zone (halo size) of $9 \mathrm{~mm}$ or more appearing around the holes, indicating presence of antimicrobial substance in the extracts tested.

\subsection{Determination of minimal inhibition concentration (MIC)}

The lowest concentration of the extractions where the effect is smaller is considered as the minimal inhibitory concentration.

\subsection{Data analysis}

ANOVA analysis is used to test the significance different of the results between the three different of plants extracts and the differences in the concentration.

\section{Results and Discussion}

3.1 In vitro antimicrobial activity of $A$. vera, $C$. hystrix, Z. officinale and Sabah Snake Grass extraction against $B$. subtilis bacteria

Studies on medical application and antimicrobial activity have been widely attested as mandatory [11-16]. In this study, the antibacterial activity was evaluated by disc diffusion method. The test was carried out using different concentration of each plant extracts. The zones of inhibition of B. subtilis were measured by ruler. The test was carried out using different concentration of each plants extracts from $5 \mathrm{mg} / \mathrm{ml}$ to 30 $\mathrm{mg} / \mathrm{ml}$. The zones of inhibition of B. subtilis were measured by ruler and shown in Table 1. It was observed that there were significant inhibition zone present in the pathogenic bacteria of B. subtilis tested with three different types of plant extractions at Figure 4 showed the antibacterial testing of three different plant extracts.
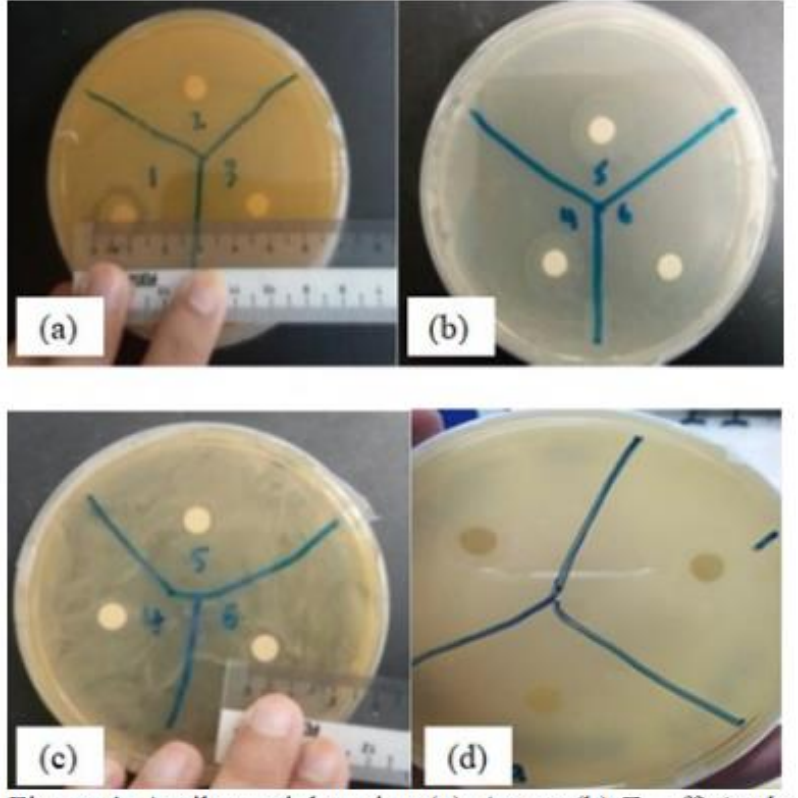

Figure 4: Antibacterial testing (a) A.vera (b) Z. officinale (c) C. hytrix (d) Snake grass

According to Table 1, zone of inhibition of ethanol A.vera extract against $B$. subtilis increases from $9.22 \mathrm{~mm}$ at $5 \mathrm{mg} / \mathrm{ml}$ to $9.56 \mathrm{~mm}$ at $30 \mathrm{mg} / \mathrm{ml}$, zone of inhibition of ethanol C.hystrix extract against $B$. subtilis increases from $8.00 \mathrm{~mm}$ at $5 \mathrm{mg} / \mathrm{ml}$ to $9.34 \mathrm{~mm}$ at $20 \mathrm{mg} / \mathrm{ml}$ but then decrease to $9.06 \mathrm{~mm}$ at $30 \mathrm{mg} / \mathrm{ml}$, zone of inhibition of ethanol Z.officinale extract against B. subtilis increases from $8.45 \mathrm{~mm}$ at $5 \mathrm{mg} / \mathrm{ml}$ to $9.50 \mathrm{~mm}$ at 20 $\mathrm{mg} / \mathrm{ml}$, and decrease to $9.17 \mathrm{~mm}$ at $30 \mathrm{mg} / \mathrm{ml}$. Lastly, zone of inhibition of ethanol Sabah Snake Grass extract against $B$. subtilis increases from $10.00 \mathrm{~mm}$ at $5 \mathrm{mg} / \mathrm{ml}$ to $11.21 \mathrm{~mm}$ at $30 \mathrm{mg} / \mathrm{ml}$ Figure 5 compares the differences between concentrations of the four plants extract with zone of inhibition against $B$. subtilis.

\section{Table 1: Zone of inhibition on the bacteria}

\begin{tabular}{|c|c|c|c|c|c|c|}
\hline \multirow{3}{*}{ Plant Extract } & \multicolumn{4}{|c|}{ Concentration of extract $\mathrm{mg} / \mathrm{ml}$} & \multirow{2}{*}{$\begin{array}{l}\text { Positive } \\
\text { control }\end{array}$} & \multirow{2}{*}{$\begin{array}{l}\text { Negative } \\
\text { control }\end{array}$} \\
\hline & 5 & 10 & 20 & 30 & & \\
\hline & \multicolumn{6}{|c|}{ Zone of Inhibition (mm) } \\
\hline Zofficinale & 5.45 & 6.94 & 9.5 & 9.89 & 12 & 6 \\
\hline C.hystrix & 6 & 7.06 & 9.34 & 10.68 & 10 & 6 \\
\hline A.vera & 7.22 & 8.39 & 9.39 & 10.98 & 15 & 6 \\
\hline $\begin{array}{l}\text { Sabah Snake } \\
\text { Grass }\end{array}$ & 8 & 10.72 & 11.33 & 13.87 & 18 & 6 \\
\hline
\end{tabular}

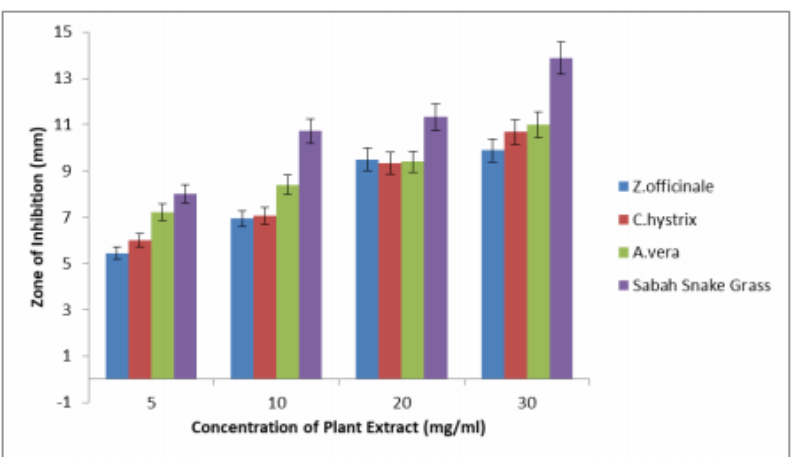

Figure 5: Bar chart of inhibition zone on bacteria for antibacterial activity 
As the concentration of the plant extracts increased, the zone of inhibition is increased.Comparing between the A.vera, C.hystrix, Z.officinale and Sabah Snake Grass ethanol extract, the extraction of Snake Grass has demonstrated higher mean of inhibition zone on B.subtilis bacteria. Followed by the second highest zone of inhibition which is Aloe vera, third was Z.officinale and lastly from C.hystrix extraction. The highest inhibition zone of Sabah Snake Grass extract was observed on the concentration $30 \mathrm{mg} / \mathrm{ml}$ with the diameter of $13.87 \mathrm{~mm}$, which is the highest of all the extract used, A.vera extract was observed on the concentration of $30 \mathrm{mg} / \mathrm{ml}$ with the diameter of $10.98 \mathrm{~mm}$ whereas C.hystrix and Z.officinale extract was observed on the $10.68 \mathrm{~mm}$ and $9.89 \mathrm{~mm}$ diameter respectively. The negative control used is distilled water. There is no inhibition zones for the negative control that showing in distilled water; this proves that the distilled water is not the antibacterial agent. For the positive control, which is DMSO, there is inhibition zone shown which concluded that DMSO can be used as an antibacterial agent. From ANOVA analysis, p-value of the four different concentrations, is smaller than 0.05 . This means that there is significant difference between the data. However, there is no significant difference between type of plant extractions (A. vera, C. hystrix, Z. officinale and Sabah Snake Grass) as the p-value is larger than 0.05 . The minimum inhibitory concentration (MIC) was performed by a serial dilution technique using microlitre pipette. MIC record the lowest concentration of plants extract that inhibit the bacterial growth. From the results, the MIC was recorded at the concentrations of $5 \mathrm{mg} / \mathrm{ml}$. The results clearly demonstrated that A. Vera, C. hystrix, Z. officinale and Sabah Snake Grass possess antimicrobial activity.

\section{Conclusions}

In this study, antimicrobial activity of extracts from Aloe vera leaf, Citrus hystrix leaf, Zingiber officinale and Sabah snake grass against Bacillus subtilis was determined. The results showed concentrations with 20 and $30 \mathrm{mg} / \mathrm{ml}$, exhibit more diameter of inhibition zone compared to lower concentration value. The antibacterial activities of different plant extracts were dependent on the concentration of the extracts. Snake grass extraction showed the highest result in antibacterial activity against $B$. subtilis followed by $A$. vera, $Z$. officinale and $C$. hystrix extractions. In a conclusion, the extraction of Sabah snake grass, A. vera, C. hystrix and $Z$. officinale produced a marked inhibitory effect on $B$. subtilis. The antimicrobial activity against the test isolates is an indication for the possibility of sourcing alternative antibiotics and antifungal substances from these plants for the development of newer antibacterial agents to combat various diseases. The use of plant extracts with known antimicrobial properties can be of great significance in disease treatments. Therefore, Sabah snake grass, $A$. vera, $C$. hystrix and $Z$. officinale plants are useful natural sources to fight against certain bacterial and fungal infections.

\section{References}

1. Y. T. Redda, E. Kebede, C. Cruz, G. Gugsa, P. O. Box, Int. J. Microbiol. Res. 5 (2014) 202-207.

2. T. S. Ramasubramaniam, V. Sivakumar, T. Arasu, J. Biosci. Res. 1 (2010) 251-258.

3. A. Bele, A. A. Bele, and A. Khale, Asian J. Pharm. Technol.
4. N. Ratseewo, J., Tangkhawanit, E., Meeso, N., Kaewseejan, Int. Food Res. 23 (2016) 188-196.

5. A. Sebiomo, A. D. Awofodu, A. O. Awosanya, F. E. Awotona, A. J. Ajayi, J. Microbiol. Antimicrob. 3 (2011) 18-22.

6. K. Islam, A. A. Rowsni, M. Khan, S. Kabir, Int. J. Sci. Environ. Technol. 3 (2014) 867-871.

7. H. Riaz, A. Begum, S. A. Raza, Z. M. Khan, H. Yousaf, A. Tariq, Int. Curr. Pharm. J. 4 (2015) 405409.

8. R. Saad, L. Wai, N. Hanif, E. Yusuf, and F. Asmani, Int. J. Pharm. Anal. Res. 3 (2014) 262-268.

9. T. Koizumi, N. Tsujiuchi, K. Inaba, and Y. Matsumura, "Identification Method," Isol. Identif. Bact. 6 (2016) 24.

10. R. A. Valverde, L. Stanley, P. Iii, J. Plant Pathol. Microbiol. 4 (2013) 1-8.

11. S. Anniebell, S.C.B. Gopinath, Curr Med Chem. 24 (2017) [Epub ahead of print].

12. K.H. Suk, S.C.B. Gopinath, Curr Med Chem. (2017) [Epub ahead of print].

13. S. Ramanathan, S.C.B. Gopinath, Microsyst. Technol. 23 (2017) 4345-4357.

14. M.E.Foo,S.C.B.Gopinath. Biomed. Pharmacotherapy 94 (2017) 354-361.

15. N.Z. Jin, S. Anniebell, S.C.B. Gopinath, Y. Chen, Nanoscale Res. Lett. 11 (2016) 399.

16. P. Velusamy, C.-H. Su, G. Venkat Kumar, S. Adhikary, K. Pandian, S.C.B. Gopinath, Y. Chen, P. Anbu, PLoS One, 11 (2016) e0157612. 